\title{
ANALISIS DAYA SERAP UN SISWA SMP DI TINJAU DARI STANDAR NASIONAL PENDIDIKAN
}

\author{
Intan Mustikasari $^{1}$, Sajidan $^{2}$, Puguh Karyanto ${ }^{3}$ \\ ${ }^{1}$ Universitas Sebelas Maret, Surakarta, 57126 \\ Email Korespondensi: intanmust1kasar1@student.uns.ac.id
}

Diajukan: 12 January 2020; Diterima: 18 February 2020; Diterbitkan: 30 April 2020

\begin{abstract}
Abstrak: Tuntutan di era kemajuan pendidikan dalam abad 21 dalam kurikulum 2013 revisi 2017 memiliki keterampilan yang harus saling berkesinambungan dalam mencetak peserta didik yang berkarakter dan memiliki wawasan ilmiah. Dalam proses pembelajaran sains di tingkat satuan Pendidikan khususnya tingkat menengah pertama dalam mata pelajaran ipa masih perlu adanya perbaikan bahan ajar yang di perbaharui guna peningkatan kompetensi siswa. Tujuan dari penelitian ini adalah untuk menganalisa daya serap UN pada satuan pendidikan tersebut. Penelitian ini dilakukan dengan metode penelitian deskriptif. Subjek penelitian ini adalah peserta didik kelas XI SMP Boyolali. Data hasil UN siswa 3 tahun terakhir dikumpulkan menggunakan data Pusat Penilaian Pendidikan Nasional (PusPenDikNas) dan dianalisis menggunakan instrumen Standar Nasional Pendidikan (SNP) sebanyak 8 Standar. Hasil analisis dari bahan ajar yang digunakan di sekolah tersebut menunjukkan bahwa persentase gab atau permasalahan tertinggi pada standar proses yaitu sebesar 4,63\%. Hal ini menunjukkan bahwa bahan ajar yang masih di gunakan di sekolah perlu untuk ditingkatkan, oleh karena itu bahan ajar harus menjadi perhatian dalam proses pembelajaran sains siswa.
\end{abstract}

Kata kunci : SNP, IPA, Kemajuan Pendidikan

\begin{abstract}
The demands in the era of educational progress in the 21 st century in the 2013 revised 2017 curriculum have skills that must be mutually sustainable in producing students who have character and have scientific insight. In the process of learning science at the education unit level, especially the junior secondary level in science subjects, it is still necessary to improve teaching materials which are updated to increase student competence. The purpose of this study was to analyze the absorption of the National Examination in the education unit. This research was conducted by descriptive research method. The subjects of this study were students of class XI SMP Boyolali. Data on student exam results for the last 3 years was collected using data from the National Education Assessment Center (PusPenDikNas) and analyzed using the National Education Standards (SNP) instrument as many as 8 standards. The results of the analysis of the teaching materials used in the school showed that the highest percentage of problems or problems in the standard process was $4.63 \%$. This shows that teaching materials that are still used in schools need to be improved, therefore teaching materials must be a concern in the students' science learning process.
\end{abstract}

Keywords: SNP, Science, Educational Progress

\section{Pendahuluan}

Sains dan pembelajaran Sains tidak hanya sekadar pengetahuan yang bersifat ilmiah saja. Melainkan terdapat muatan sains, keterampilan proses dan dimensi yang terfokus pada karakteristik sikap dan watak ilmiah (BSNP, 2006). Pembelajaran Sains diharapkan mampu menanamkan dan membudayakan kebiasaan berpikir dan berperilaku ilmiah yang kritis, kreatif dan mandiri. Hal ini berdampak pada peran guru yang bergeser dari penyampai pengetahuan menjadi agen pendidikan dalam pembelajaran Sains yang lebih memfokuskan pada aktivitas siswa (Tim Pengembang Ilmu Pendidikan FIP-UPI. 2011:200).

Kualitas pendidikan masih terbilang sangat jauh dikarenakan salah satu sebab rendahnya mutu lulusan adalah belum efektifnya proses pembelajaran. Proses pembelajaran selama ini masih terlalu berorientasi terhadap penguasaan teori dan hafalan dalam semua bidang studi yang menyebabkan kemampuan belajar peserta didik menjadi terhambat. Metode pembelajaran yang terlalu berorientasi pada guru (teacher oriented) cenderung mengabaikan hak-hak dan kebutuhan, serta pertumbuhan dan perkembangan anak sehingga proses 
pembelajaran yang menyenangkan, mengasyikkan, dan mencerdaskan menjadi kurang maksimal. Di sisi lain, guru harus merencanakan dan mempersiapkan secara holistik untuk memfasilitasi siswa dalam pembelajaran kontekstual, partisipatif, aktif, dan kreatif (Muhfahroyin \& Oka, 2017).

Selain bahan ajar yang digunakan oleh guru masih belum maksimal, hal ini menjadi perhatian khusus untuk di teliti karena membutuhkan analisis. Selain itu ujian nasional (UN) sebagai basis pengukuran kemampuan peserta didik di SMP Muhammadiyah Program Khusus Boyolali. Pusat Penilaian Pendidikan Nasional (PUSPENDIKNAS) mengupdate hasil ujian nasional yang dikelola oleh kementerian pendidikan dan kebudayaan. Dari segi pembelajaran berbasis pembelajaran inkuiri merupakan pembelajaran yang menekankan pada proses berpikir kritis, analitis, kreatif untuk mencari da menemukan sendiri jawaban dari suatu permasalahan (Salavera, Usán, Chaverri, Gracia, \& Aure, 2017; Wenning et al., 2006).

\section{Metode Penelitian}

Tujuan dari penelitian adalah untuk menganalisis daya serap UN siswa SMP berbasis Standar Nasional Pendidikan (SNP). Subjek dari penelitian adalah siswa kelas IX SMP di Boyolali. Penelitian dilakukan dengan metode deskriptif. Instrumen yang digunakan adalah SNP 8 standar dan hasil daya serap ujian nasional di tahun 2014/2015, 2015/2016 dan 2016/2017 ditahun tahun secara berurutan. 8 standar yang di ambil datanya meliputi standar isi, proses, kompetensi lulusan, pendidik dan tenaga kependidikan, sarana dan prasarana, pengelolaan, pembiayaan dan penilaian. Dalam hal ini yang memperoleh permasalahan atau gab yang persentasenya besar adalah standar proses sebesar 4,63\%. 8 standar tersebut masing - masing memiliki lebih dari satu indikator. Standar isi memiliki 8 indikator, standar proses 10 indikator, standar kompetensi lulusan 12 indikator, standar pendidik dan tenaga kependidikan 11 indikator, standar sarana dan prasarana 11 indikator, standar pengelolaan 4 indikator, standar pembiayaan 3 indikator dan standar penilaian 13 indikator. Pengumpulan data dalam penelitian ini menggunakan studi literatur melalui data puspendiknas, wawancara langsung dan mengisi angket oleh praktisi pendidikan di SMP Program Khusus Muhammadiyah tersebut.

\section{Hasil Penelitian dan Pembahasan}

Tabel 1. Persentase Hasil SNP dan GAP pada 8 Standar

\begin{tabular}{|c|c|c|c|c|c|c|c|}
\hline & $\begin{array}{c}\text { Jumla } \\
\text { h }\end{array}$ & $\begin{array}{l}\text { Sk } \\
\text { or }\end{array}$ & $\begin{array}{c}\text { SN } \\
\mathbf{P}\end{array}$ & $\begin{array}{c}\text { GA } \\
\mathbf{P}\end{array}$ & & $\begin{array}{l}\text { Sk } \\
\text { or }\end{array}$ & \\
\hline & $\begin{array}{c}\text { Indik } \\
\text { ator }\end{array}$ & $\begin{array}{c}\text { Ide } \\
\text { al }\end{array}$ & $\%$ & $\%$ & $\begin{array}{l}\text { M } \\
\text { in }\end{array}$ & $\begin{array}{l}\text { M } \\
\text { ax }\end{array}$ & $\begin{array}{c}\text { Me } \\
\text { an }\end{array}$ \\
\hline STAND & & & 7.4 & 3.7 & & & 2.0 \\
\hline AR 1 & 8 & 24 & 1 & 0 & 1 & 3 & 0 \\
\hline STAND & & & 9.2 & 4.6 & & & 2.0 \\
\hline AR 2 & 10 & 30 & 6 & 3 & 1 & 3 & 0 \\
\hline STAND & & & 13. & 2.7 & & & 2.5 \\
\hline AR 3 & 12 & 36 & 89 & 8 & 3 & 3 & 0 \\
\hline STAND & & & 11. & 3.7 & & & 2.2 \\
\hline AR 4 & 11 & 33 & 57 & 0 & 1 & 3 & 7 \\
\hline STAND & & & 9.2 & 6.0 & & & 1.8 \\
\hline AR 5 & 11 & 33 & 6 & 2 & 3 & 3 & 2 \\
\hline STAND & & & 4.1 & 1.3 & & & 2.2 \\
\hline AR 6 & 4 & 12 & 7 & 9 & 3 & 3 & 5 \\
\hline STAND & & & 2.7 & 1.3 & & & 2.0 \\
\hline AR 7 & 3 & 9 & 8 & 9 & 2 & 3 & 0 \\
\hline STAND & & & 14. & 3.2 & & & 2.4 \\
\hline \multirow[t]{2}{*}{ AR 8} & 13 & 39 & 81 & 4 & 1 & 3 & 6 \\
\hline & & 21 & 73. & 26. & & & \\
\hline TOTAL & 72 & 6 & 15 & 85 & & & \\
\hline
\end{tabular}

Berdasarkan data diatas dapat dilihat bahwa perbedaan antara data real dan data ideal (GAP) tertinggi terdapat pada standar kelima yaitu standar sarana dan prasarana dengan nilai gap $6.02 \%$. Selain itu gap tertinggi kedua diperlihatkan pada standar kedua yaitu standar proses dengan nilai gap sebesar $4.63 \%$. Hal tersebut menunjukkan bahwa kedua standar tersebut masih perlu mendapatkan perbaikan. Standar proses mendapatkan nilai gap yang tinggi dikarenakan penerapan pembelajaran dengan apa yang sudah tercantum di RPP masih berbeda saat pembelajaran berlangsung. Selain itu, kegiatan penggunaan media pembelajaran, metode dan model yang bervariasi, serta pemanfaatan ICT dalam pembelajaran masih kurang optimal dilakukan dengan baik oleh guru.

Standar dengan gap tertinggi adalah standar sarana dan pra sarana. Standar ini masih membutuhkan banyak bantuan dan alat-alat untuk menunjang proses belajar mengajar. Guru masih menggunakan media seadanya untuk menunjang proses belajar. Dikarenakan sekolah ini sempat mati suri dan berdiri lagi 
tahun 2009, sehingga pemenuhan sarana dan pra sarananya masih kurang sekali

Adapun Diagram SNP SMP Muhammadiyah PK Boyolali

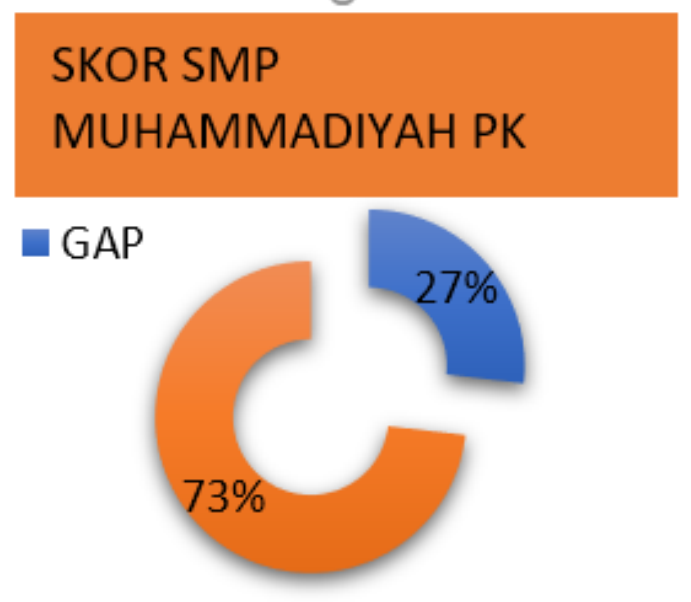

Diagram 1. Persentase Hasil SNP dan GAP pada 8 Standar Nasional Pendidikan

Diagram GAP SNP tersebut menunjukkan bahwa analisis dari keseluruhan standar (standar 1 sampai standar 8) memiliki skor sebesar 26,85\% dan untuk perolehan skor SNP sebesar 73,15\%. Skor GAP yang tidak terlalu besar tersebut diperlukan perbaikan dengan menambah sarana yang belum dimiliki oleh sekolah, selain itu seperti pra sarana seperti laboratorium itu harus di gunakan dan di kembangkan untuk melakukan praktikum. Sehingga adanya perbaikan dan penambahan sarana ini dapat meningkatkan kualitas mutu suatu sekolah dan meningkatkan sumber daya manusia untuk terus mengembangkan sekolah ini.

\section{Analisis Hasil Ujian Nasional Daya Serap UN Mata Pelajaran IPA}

Analisis daya serap ujian nasional untuk SMP Muhammadiyah PK Boyolali yang dilakukan adalah pada ujian nasional 3 tahun terakhir yaitu tahun ajaran 2014/2015, 2015/2016 dan 2016/2017. Analisis ini bertujuan untuk memetakan indikator-indikator materi yang nilainya paling rendah jika dibandingkan dengan daya serap materi-materi lainnya.

Daya serap berdasarkan indikator terendah tahun ajaran 2014/2015 adalah pada mendekripsikan atom, ion, atau molekul seta hubungannya dengan produk kimia sehari-hari berdasarkan pemakaiannya dengan nilai daya serap sebesar $12.90 \%$. Nilai rata-rata daya serap pada tahun ajaran 2014/2015 adalah sebesar $31.67 \%$. Secara lebih jelas daya serap terendah berdasarkan indikator disajikan dalam potongan tabel berikut ini.

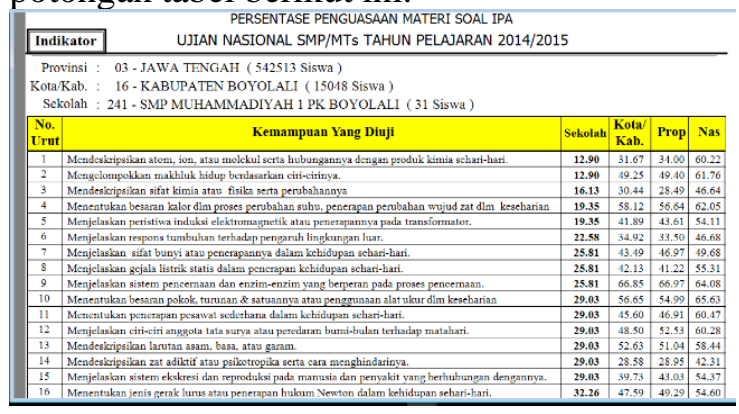

Berdasarkan hasil pengamatan selanjutnya, didapatkan bahwa nilai terendah kemampuan yang diujikan pada UN tahun ajaran 2015/2016 adalah kemampuan dalam menentukan sifat suatu larutan berdasarkan pemakaiannya dengan nilai daya serap sebesar $5.26 \%$. Nilai rata-rata daya serap pada tahun ajaran 2015/2016 adalah sebesar 16.57\% . Secara lebih jelas daya serap terendah berdasarkan indikator disajikan dalam potongan tabel berikut ini.

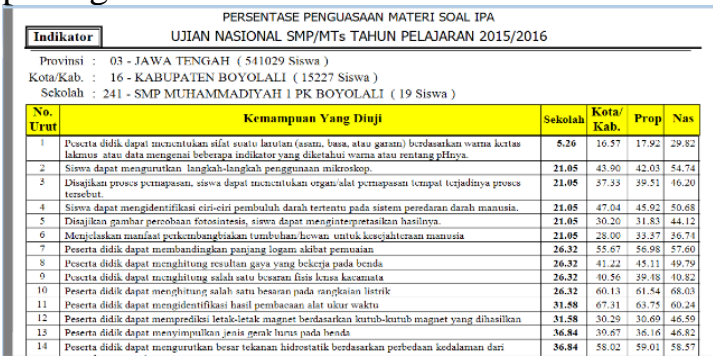

Berdasarkan hasil pengamatan selanjutnya, didapatkan bahwa nilai terendah kemampuan yang diujikan pada UN tahun ajaran 2016/2017 adalah ayunan sederhana. berdasarkan pemakaiannya dengan nilai daya serap sebesar $4.55 \%$. Nilai rata-rata daya serap pada tahun ajaran 2016/2017 adalah sebesar $36.02 \%$. Secara lebih jelas daya serap terendah berdasarkan indikator disajikan dalam potongan tabel berikut ini. 


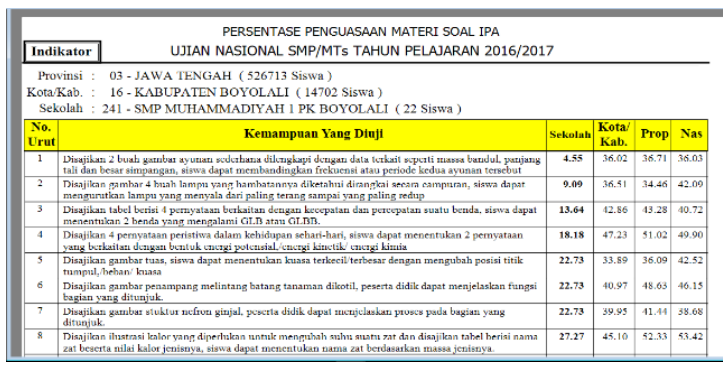

\section{Simpulan, Saran, dan Rekomendasi}

Dari ketiga hasil daya serap Ujian Nasional (UN) di SMP Muhammadiyah PK Boyolali bahwasanya daya serap UN masih tergolong rendah, oleh karena itu perlu adanya evaluasi dan perbaikan kualitas bahan ajar guna menunjang sistem pembelajaran di abad 21 era revolusi 4.0, sehingga dapat mengurangi gap atau masalah daya serap ujian nasional yang masih tinggi. Selain itu bahan ajar yang digunakan semoga dapat memperbaiki sistem pembelajaran di sekolah tersebut. Ke depan sistem pembelajaran berbasis digital dengan kemajuan teknologi dapat mempermudah akses bahan ajar yang terstandartdisasi

\section{Daftar Pustaka}

BSNP. 2006. Permendiknas RI No. 22 Tahun 2006 tentang Standar Isi untuk Satuan Pendidikan Dasar dan Menengah. Jakarta.

Muhfahroyin, \& Oka, A.A, 2017. Improving Postgraduate Students Learning Activities through Lesson Study in Learning ForestPrototype. Biosaintifika: Journal of Biology \& Biology Education, 9(116), 311-316.

Salavera, Usán, Chaverri, Gracia, \& Aure, 2017 Emotinal Intelligence and creativity in first and second-year primary school children. Procedia - Social and Behavioral Sciences, 237(June $\quad 2016$ ), $\quad 1179 \square 1183$. https://doi.org/10.1016/j.sbspro.2017.02.176

Tim PengembangIlmu Pendidikan FIP-UPI. Ilmu Dan Aplikasi Pendidikan. Imperial Bhakti Utama; 2011. h. 200.

Wenning, C. J. Teacher, P., \& Program, E. (2006). A framework for teaching the nature of science. 